\title{
VR-Technology in Teaching: Opportunities and Challenges
}

\author{
Caroline Graeske ${ }^{1} \&$ Sofia Aspling Sjöberg ${ }^{2}$ \\ ${ }^{1}$ Department of Health, Education and Technology, Luleå University of Technology, Luleå, Sweden \\ ${ }^{2}$ NTI-Gymnasium, Trädgårdsgatan 22, Luleå, Sweden \\ Correspondence: Caroline Graeske, Department of Health, Education and Technology, Luleå University of \\ Technology, Luleå, Sweden. E-mail: caroline.graeske@ltu.se
}

Received: March 29, 2021

Accepted: May 17, $2021 \quad$ Online Published: July 27, 2021

doi:10.5539/ies.v14n8p76

URL: https://doi.org/10.5539/ies.v14n8p76

\begin{abstract}
Use of virtual reality (VR) to teach in upper-secondary schools has become more common during recent years. This article discusses the implementation and testing of VR to teach Swedish in upper-secondary school, a pilot study carried out during the 2020/2021. The purpose of this study is to investigate how VR can be used to teach Swedish, what possibilities and challenges arise from using VR as a learning resource. The method used was inspired by action-based research, where teachers and researchers together, in a symmetrical and complementary approach, explore and evaluate an action. Central theoretical perspectives were TPACK-competences and design principles for gamified learning. The results indicate that students' motivation increases by possibilities to co-create, co-design and customize their own learning, where the students solve problems and consider and reflect on their own learning. Both students and teachers point out didactical potentials and explain that VR technology offers many opportunities, but cannot exist on its own. It must function in accordance with the curriculum and regulatory documents of the educational institution.
\end{abstract}

Keywords: action-based research, gamified teaching, upper secondary school, Swedish subject, VR-technology

\section{Introduction}

Use of virtual reality (VR) to teach in upper-secondary schools has become more common during recent years. VR equipment has grown more affordable and more user-friendly. Much indicates that VR will be a more conventional tool in the future schools (Fransson et al., 2020). Today, more frequent use of VR occurs in some adult education programs, for example, in engineering and medicine, because VR enables simulations and visualizations of various scenarios and phenomena. However, VR also shows great potential in other fields of teaching, because the technology encourages and motivates learning through intense three-dimensional experiences (Lucas 2018; Zhou et al., 2019). Recently, graphics have improved immensely, partly due to a strong gaming industry that encourages technological development, allowing users to easily, and without risk, move across time and space, as well as encounter new worlds.

\subsection{Purpose and Aim}

This article discusses the implementation and testing of VR to teach Swedish in upper-secondary school, a pilot study carried out during the 2020/2021 academic year. The project was initiated by the principal of the school, pursuant to a goal to incorporate more digital tools in the curriculum, and because several teachers had experienced that students were unmotivated to read and write. The purpose of this study is to investigate how VR can be used to teach Swedish. What possibilities and challenges arise from using VR as a learning resource? What is the didactical potential of VR?

Students' commitment and desire to learn have proven to be important connected to achievement (Baker, Dreher, \& Guthrie, 2000; Guthrie \& Wigfield, 1997) and the ambition was that VR technology would improve the students' commitment and motivation to read and write. In order to better evaluate the results of VR in the curriculum, an action-research project was initiated, a pilot study, where teachers and researchers worked together. The intent with the project was to investigate how VR works in teaching situations, in order to motivate students to read and write longer texts.

\subsection{Previous Research}

Previous research regarding usage of VR has indicated several advantages. For example, VR can be used to expose 
users and offer safe education in realistic situations (Jensen \& Konrdsen 2018; Franson et al., 2020; Mathe, 2020). Even advantages with VR technology in teaching have been proven. Häfner et al. (2018) highlight seven important aspects: 1.) Improved motivation, 2.) More efficient communication and evaluation, 3.) Better understanding of complex systems through good graphics, 4.) Possible adaptation after individual needs, 5.) High security, 6.) Environmental friendliness and little usage of material, 7.) Cost-effectiveness (Häfner el al. 2018).

Beyond these factors, strong experiences that can motivate and accelerate learning (Shu et al., 2019; Kwon 2019) have been highlighted, and in a more recent Swedish study researchers show that VR can generate enhanced commitment in students studying history (Franson et al., 2020).

The advantages with VR in learning situations are thus many, but they are not undisputed. Researchers have, for example, shown that simulation in laboratories also can lead to cognitive overload, which degrades learning (Makransky et al., 2019). Another effect that has been proven is dizziness and sensory unbalance and nausea among users, mostly amongst adults (Rebenitsh \& Owen, 2016; Kawai \& Häkkinen, 2019) but also amongst school children (Kwon 2019). Another identified challenge is that the equipment can be very expensive and difficult to use. VR equipment demands a certain technical expertise, and it can be challenging to get a hold of relevant content. The students must usually share VR equipment, which requires logistics and good planning. In addition it may be difficult to acquire relevant software, since much of the software is based on single experiences, rather than learning through progression (Jensen \& Konradsen, 2018; Fransson et al., 2020).

Language is another challenge, since VR applications often are produced in English, and therefore complicate use of VR for younger children. Minocha et al. (2017) has also indicated the limited possibilities for teachers to get continuous competence development in order to use VR in a relevant way in both compulsory and upper secondary school.

The challenges to use VR in educational contexts are thus numerous, but most are logistical, involving budgets, time, and planning. However, as concerns learning, the positive effects are difficult to measure but seem to outweigh the negative effects. Still, very few studies regarding VR have been done in the Swedish school context (cf Fransson et al., 2020). Fransson et al., (2020) who have investigated the use of VR to teach history, have indicated certain benefits from using VR in education, but also the difficulties of measuring the effects of VR, making it urgent to continue researching the didactical potential of VR technology. The purpose of this study is therefore to investigate how VR can be used to teach Swedish. What possibilities and challenges arise from using VR?

\section{Method}

In autumn 2020, a VR project was initiated by a teaching team at an upper-secondary school in a medium-sized municipality in Sweden. A total of seven teachers in the teaching team ensued the project, of which two participated actively. The study was implemented in two classes enrolled in 'Swedish 1', one class from The Technical Programme and another attending The Electrical and Energy Programme, together with two teachers and a researcher. In addition, an English teacher participated.

\subsection{Action Based Research}

The method used was inspired by 'action-based research,' where teachers and researchers together, in a symmetrical and complementary approach, explore and evaluate an action for the purpose of changing something (Hardy \& Rönnerman, 2018; Rönnerman, 2012; Tiller 1999). In dialogue with researchers, a "desired destination" (Bergmark \& Wiklund 2020) was established, in this case the desire to increase the students' motivation to read and write. In dialogue with the teachers, it emerged that students showed great resistance to writing texts, especially students in The Electrical and Energy Programme. The teachers experienced that students found it difficult to start writing and reading, and difficult to find motivation or momentum. To use new digital resources to stimulate learning was a goal expressed by administrators at the school. The previous year, a teacher attempted to incorporate VR in her Swedish classes, upon the initiative of the principal. She was eager to follow up and further develop the project. During one of the teachers'weekly meetings, it was decided that a new VR project would be implemented. At the meeting, it was also decided which teachers would participate in the project. These teachers, together with the principal and the researcher, established the framework for the project.

As a first step, a workshop was arranged, where the teaching staff could try VR. The purpose was to acquaint and familiarize teachers with the technology. An intention was also to inspire other colleagues to use VR in their teaching.

In addition to the workshop, meetings were being held approximately every other week through autumn 2020, where teachers and researchers discussed the project, and teachers learned more about ongoing university research 
into digital teaching aids and didactical design, including a study about using avatars when reading classics (Thunberg, 2020; Graeske et al., 2020). The aim was to further inspire teachers to use different digital learning resources to stimulate student writing and reading.

Planning of VR classes in 'Swedish 1' commenced at the beginning of the semester. Preparations included a detailed presentation to students, during the initial class, regarding the purpose and the assignment at hand. The purpose of the assignment presented to the students attending The Technical Programme was to write a user's manual for a game of their own choosing. Also included in the assignment were instructions for starting a VR unit, and considerations for this process. Students attending The Electrical- and Energy Programme were instead assigned to write a reflection regarding a gaming experience.

Students used VR during one 80-minute lesson. They were then expected to complete the writing assignment during another 80-minute class. Assignments were to be completed individually, for credits towards 'Swedish 1,' the core content of which focuses on writing texts in order to communicate, learn, and reflect (SKOLFS 2011:144). To be noted is that there are examination objectives related to computer technology in the general description of The Electrical- and Energy Programme written by National Agency of Education (Skolverket). In these examination objectives it is mentioned that education should focus on computer technology among other things. Similar examination objectives, as well as the goal to develop skills within the area of technology can be found in the general description of The Technical Programme (SKOLFS 2011:144).

\subsection{Questionnaire and Interviews}

Participating students also answered a questionnaire prior to and after completing the VR and writing classes. The questions dealt with students' expectations regarding VR in education, as well as previous experiences with VR and other digital educational materials. In total, 28 students attending The Technical Programme answered the first questionnaire, and 22 answered the second. 18 students attending The Electrical and Energy Programme completed the first questionnaire, while 16 completed the second.

Interviews were also conducted with two teachers using VR in their classes. All interviews during the fall of 2020 were carried out after the VR assignment had ended. The interviewed teachers had 17 years and 16 years of professional experience respectively. The interview questions were about planning and use of teaching materials in education, and about experiences using digital teaching aids, including VR. The interviews can be considered conversations, where researcher and teacher discuss and reflect, and the intention was for the dialogue to become a positive experience and enriching for the interviewee as well (Bryman 2018). That teachers in subjects other than Swedish were interviewed is due to the interdisciplinary nature of the school. This VR session was planned together. During the interviews, an interview guide consisting of semi-structured questions was used. All interviews were recorded and transcribed (Bryman, 2018). The teachers' utterances have been categorized as well as thermalized. The themes have been crystallized during an abductive interpretation process (Burawoy, 1998). In addition, reflective conversations were carried out, where researchers and teachers discussed the results of the action, with previous research and theoretical perspectives in mind.

\subsection{Theoretical Perspectives}

A central theoretical point of departure for this study is TPACK ('Technical, Pedagogical and Content Knowledge'), a pedagogical tool that illustrates necessary teaching competences, based on the theories of American pedagogy researcher Shulman (Koehler \& Mishra, 2008). Shulman expressed his thoughts on a special teaching competence, based on a combination of pure subject competence and the teachers' pedagogical competence, over thirty years ago (Shulman, 1986). "Content Knowledge" is a description of the teacher's subject knowledge and may involve anything from spelling to profound subject knowledge, depending on education level. Knowledge based on facts is therefore important, but "Pedagogical Knowledge" is also essential, according to Shulman. The teacher must be able to adjust their material to the target group, and be aware of students' differing needs. Pedagogical competence also involves the ability to use different teaching methods to simplify learning for students. Not until the teacher can combine these competences is "Pedagogical-Content Knowledge" generated.

TPACK, furthermore, is a development based on Shulman's ideas, to which researchers Koehler \& Mishra (2008) add what they believe an essential part of teaching competence, namely "Technological Knowledge," which foremost involves an open approach to digital technology, while TPACK-competence concerns the art of integrating digital technology into pedagogy and subject matter. TPACK then shows the complex relationship between technology, pedagogy and subject in a given teaching situation.

TPACK has been criticized by various researchers, in particular, for its lack of clarity regarding operationalization and conversion of the framework (Willermark, 2018). Even if teachers have knowledge, and experience, with 
digital technology, they might still be unable to convert this knowledge into hands-on action, and then evaluate it. In this context, however, TPACK is used as a configurable grid in analyses of the teaching situation. The TPACK model was presented to and discussed with participating teachers, who were given the opportunity to reflect upon the various competences, and how to incorporate them into didactical planning of VR and other technology. To operationalize the framework further with the project goals in mind, Gert Biesta's theories about teaching, and Paul Gee's theories about gaming principles and literacy, were used (Biesta, 2010; 2013; Gee, 2008; Gee \& Hayes, 2011). These theories were also discussed with teachers.

Biesta, who focused on philosophical questions related to the tension between learning and teaching, is relevant in this context, since he has so clearly indicated the difficulties in measuring teaching (Biesta, 2010). Biesta claims, for example, that a shift in focus has occurred from the teacher's activity to the student's, where the teacher's mission is to ease the student's learning. He also mentions the disintegration of the welfare state, and shows how evaluations of different kinds become important when students and parents turn into consumers. Biesta is very critical of this development, as well as being critical of tendencies towards evidence-based and measurable learning. All activities in school cannot be measured, and values that are not measurable may be lost, for example, the basic principles and culture of the school (Biesta, 2010). Biesta also claims that every teaching situation is very complex, involving many different parameters of essence for the result, making it difficult to determine general evidence-based teaching methods (Biesta, 2010). These viewpoints have been integral to this study. Focus has been on motivating students and creating opportunities where students and teachers reflect upon teaching situations. This has been important because learning and teaching are not synonymous (Biesta, 2010, 2013). A teaching situation is rather when students are given the opportunity to reflect on something presented by their teacher. This 'something' can offer new conceptual worlds and insight into uncharted territory, an approach that is important in this context.

Another theoretician of relevance in interpretation of our outcome is the American media researcher Paul Gee. His design principles for gamified learning can, in this context, contribute to increased understanding of what happens in the teaching situation. Gee has presented several design principles for teaching in his research, but three particular concepts from his work have influenced this study: 1) co-design, which means that the students design and build their learning themselves, 2) customization, which means that the students solve problems and reflect upon their learning, 3) identity, which means that the students embody an avatar and experience a virtual reality (Gee, 2008). These three design principles have guided analysis of the empirical material.

\subsection{Ethical Standpoints}

During the entire undertaking the ethical guidelines that are formed by The Swedish Research Council have been applied (Vetenskapsrådet, 2017), but since the project has an action research approach the traditional view on ethics and traditionally important research considerations such as informed compliance, confidentiality and the integrity of the participants were somewhat renegotiated since researchers and teachers work together in this project. In action based research the social connections between the participants become more complex and reflections regarding anonymity and dispensation of results become important. In this context researchers and teachers have tried to work in a symmetrical and complementary atmosphere, where the action also has resulted in the co-writing of this article. The entire cooperation has further amounted to a constant reflection regarding ontological, epistemological and methodological ideas (Andrée et al., 2020). The ontological perspective includes reflection based on how the students' learning is influenced by the action and the admittance of the values at stake. In the teacher's case this considers expertise from the teaching profession and in the researcher's case about research projects and gathering of empirical data. Reflections from an epistemological perspective have also been working as guidance. These were mostly about the negotiations about a shared research object where the goals of the action became gathering of new information regarding the didactical potential for VR in education. Finally, the reflections regarding the methodological perspective were mostly about how the empirical data can be interpreted based on different teaching theories, a discussion that turned out to be educational for all parties (Andrée et al., 2020).

In the following passages the result is presented. First, a brief description of the action itself, thereafter the results of the answers from the enquiries and interviews are presented. So, what does the empirical material indicate?

\section{Results}

The action, the VR classes and the writing assignments, were all administered by the teachers following the didactical plan. During the VR lesson, the class was divided in halves and a total of five VR units were used simultaneously. Students worked in pairs in two classrooms to provide the necessary space. Most students played demonstration versions of games accessible on the VR sets. Students could choose between several different 
games, the most popular being 'Beat Saber', a sword based game. A general conclusion was that the assignment worked well, and the student performed the tasks expected of them. 46 of 48 students completed the assignment. Only one student in each class did not hand in the assignment, and one student was reported ill. The texts written were estimated by teachers to be long in comparison with 'Swedish 1' assignments, most notably in those texts written by students attending The Electrical and Energy Programme.

The student questionnaires showed that several students had tried VR prior to the class, but rarely. Half of Technical Programme students, and a comparable number of Electrical and Energy Programme, had used VR previously. But only a few students from both programmes used VR regularly, mainly for playing games. Many students from both classes expected that VR in educational situations would make them more motivated to learn. Among those attending The Technical Programme, ten students responded with five, on a scale from one to five, and 13 students, 47 percent, marked four. In The Electrical and Energy Programme, the result was similar, but here the outcome was somewhat lower; two students considered that VR would not affect their motivation for learning. However, the ensuing sections of the questionnaire show that even the students in The Electrical- and Energy Programme experienced that using VR motivated learning, and a full 44 percent of students marked the second highest alternative on the scale, and not one student marked the lowest alternative. The questionnaire also shows that all students experienced a desire to learn more and explore with VR, for example, through tours and different experiences.

Students' increased commitment appears in the teacher interviews. The students started quickly with their assignments and seemed to be very "happy" and "content" during their work (Teacher 2). Teachers notice great potential for VR, and few challenges or risks. Accordingly, the motivation to use VR seems to be prominent even amongst the teachers. Thus, a challenge is to find relevant material to work with: "What is offered in 360-videos is very limited", a teacher claims (Teacher 1).

In teacher interviews, teachers appear willing to try new approaches, and that they do not use textbooks in their teaching. Instead, the Swedish teacher uses extracts from different textbooks supplemented by material found online. The teacher resources are: "a grab bag /.../ it can be TED talks or clips from YouTube /.../ I am not stuck with one educational material". She feels that textbooks quickly get "dated" and that they are not especially "up to date" and she wishes to find other resources and teaching tools (Teacher 1).

To ensure positive results, and committed students, assignments must be planned with students:

I always start by asking the students: What do you want to work with? Since we need the students' participation. They also have a say regarding which area we are going to work with next. They get to decide, as much as they can and will, how we are going to work the study area, and they participate in deciding how I should assess them. /.../ I love to plan and think based on the group of students ahead. (Teacher 1)

Teacher 2 also points out the importance of student participation in the planning; she does not use textbooks either, creating her own materials instead. A noticeable result of VR use in education was the prompt student engagement with the assignment to write a user's manual. Some students did not even use the entire VR session, but instead expressed a desire to start writing.

Regarding challenges and risks of VR use, teachers notice few. They mention that using VR in classrooms requires good planning. The class must be divided into smaller groups, and several classrooms are needed. The equipment must be functional and charged, extra batteries should be at hand, etc. The students' possible physical limitations should be taken into consideration and planned for. There may, for example, be students unable to participate due to visual impairment. These students must then have access to other teaching resources such as, for example, films. They also mention that technical problems could be a challenge, but few emerged in this case, a fact also notable in the student questionnaire. No student experienced technical problems they were unable to easily solve. One of the teachers also highlights that 'the teacher does not always know best.' She explains that she was previously afraid to use technology, since she was unable to master it, but now has changed her mind:

Previously, I have been afraid of it, since I thought that I must master it before I unleash it on the students. But now I have come to the conclusion that, after a few years, I do not have to, since I can learn together with the students/.../and now, with VR, the outcome was very positive. (Teacher 2)

A cause for the successful result, mentioned by Teacher 2, was the students' different options. Students could choose the game they wanted to play and write about: "The students felt that they got to do something. They thought that VR was a lot of fun and to write that manual, after that, it simply just continued." (Teacher 2)

After the VR sessions, several students wanted to know more about VR technology and one further class on this topic was planned for the students. "It is a question of finding relevant assignments," says Teacher 1. A possibility 
mentioned here, by the teachers, is study visits to, for example, Shakespeare's Globe Theatre, or Anne Frank's house, or "to enter someone's writing workshop." (Teacher 1). However, teachers must reckon with a VR market still limited as to content suitable for the upper-secondary schools.

\section{Discussion}

So what opportunities and challenges arise when using VR in education? What is the didactical potential of these teaching resources?

VR, like other digital resources, work out well, and have a didactical potential, if the TPACK-competences interact and work together (Koehler \& Mishra, 2008). The teacher's didactical subject competence should thus include a technical competence. However, in terms of "Technological Knowledge," the teachers were clear regarding the importance of learning together with the students. The teacher does not always know most about the technology at hand, but this offers opportunities to explore different problems that may arise together with the students. Such a situation can stimulate students' learning.

Exploration, in particular, is central to Gee's theory. The students' motivation increases as they participate in the creation and exploration of their own studies. In his research, Gee has brought forward the design principles of co-design, which means that the students themselves design and build their learning; customization, which means that the students solve problems and consider their own learning; identity, which means that the students use and embody an avatar and experience a virtual reality being used (Gee, 2008). All of these principles are mentioned indirectly by the teachers in interviews and during reflective conversations. It appears that these elements have been important for the students' commitment and motivation to learn (Baker et al., 2000; Guthrie \& Wigfield, 1997).

The students design their own learning, to the extent that they participate in planning the education. This makes them complicit, and they feel a certain ownership regarding their learning (Gee, 2008). Subsequently, when they use VR, the feeling of participation is enhanced as students interact with technology. Also, the students actively make choices, for example, regarding the program and game they will write about. They also control the content of the VR session, which may contribute to increased motivation (Gee, 2008).

In the questionnaire, students also had the opportunity to reflect upon their motivation and learning. For example, they considered potential problems that arose and how they solved these. Students were also offered the opportunity to embody an avatar when entering a three-dimensional world. However, using technology for its own sake is not a key for success. The lesson must remain connected to a clear purpose, and the students must understand why they are completing certain assignments. All teachers participating in this project believe that VR technology has great didactical potential when it is connected to curriculums and educational goals. Teacher 1 also clarifies that she usually lets the students participate, when planning lessons, in order to feel ownership, but also to understand which goals they are working towards. However, the extent to which VR contributes to increased motivation is difficult to say. The questionnaires show that students believe their motivation increased, but it is not possible to detect measurable effects, and the question remains whether effects are even relevant here.

Biesta $(2010,2013)$ claims that each teaching environment is very complex, and that teaching and learning are not synonymous. Instead, a teaching situation involves students receiving the opportunity to reflect upon something presented by the teacher. In this context, students are complicit, making active choices in a virtual reality that offers powerful experiences favourable for learning (Shu et al., 2019; Kwon, 2019). There are other additional advantages to VR, for example, increased motivation, more efficient communication, and better understanding of complex systems through good graphics that stimulate learning (Häfner el al., 2018).

\section{Conclusion}

According to these results, VR technology offers many opportunities, but cannot exist on its own. It must function in accordance with the curricula and educational goals. However this study clearly shows that the students became very engaged and almost all students fulfilled the assignment. The teachers also found many opportunities but they also lacked relevant software for VR in upper secondary school. VR in education enables new experiences and competences, permitting students to move through time and space while remaining in the physical classroom. VR therefore affects the interpersonal relationships in the classroom, since students in the virtual world also can interact with other, virtual persons. This phenomenon shifts the horizon in the physical classroom and offers another dynamic. The student encounters new worlds, in a form already familiar to several students. In this context, it is of the utmost importance that teachers value the resource of students' previous experiences and knowledge. TPACK-competences are important, but this pilot study also makes clear that the teacher does not need to know best, when it comes to technology. VR technology creates new relations between teacher and student, 
where knowledge and the balance of power are repudiated, so that teachers and students together can explore certain phenomena. This might also motivate students who feel they 'own' the learning situation together with the teacher (Gee, 2008). Still though better software, adapted to curricula, is needed and researchers, teachers and students must therefore continue to work together in order to generate new possibilities and knowledge about VR.

\section{References}

Andrée, M., Danckwardt-Lillieström, K., \& Wiblom, J. (2020). Ethical Challenge of Symmetry in Participatory Science Education. Research Proposing a Heuristic for Ethical Reflection. In K. Otrel-Cass, M. Andrée, M. Ryu (Eds.), Examining Ethics in Contemporary Science Education Research: Being Responsive and Responsible (pp. 123-141). Berlin: Springer. https://doi.org/10.1007/978-3-030-50921-7_8

Baker, L. D., Mariam J., \& Guthrie, J. T. (2000). Why teachers should promote reading engagement. In L. D. Baker, J. Mariam, \& J. T. Guthrie (Eds.), Engaging Young Readers: Promoting Achievement and Motivation (pp. 1-16). York: Guilford Press.

Bergmark, U., \& Viklund, S. (2020). Litteratursamtalets pedagogik. Relationer, lärande, utveckling. Malmö: Gleerups.

Biesta G. (2013). The beautiful risk of education. Boulder: Paradigm Publishers.

Biesta, G. (2010). Good Education in an Age of Measurement: Ethics, Politics, Democracy. London: Routledge.

Bryman, A. (2018). Samhällsvetenskapliga metoder. Malmö: Liber.

Burawoy, M. (1998). The extended case method. Sociological Theory, 16(1), 4-33. https://doi.org/10.1111/0735-2751.00040

Fransson, G., Holmberg, J., \& Westelius, C. (2020). The challenges of using head mounted virtual reality in K-12 schools from a teacher perspective. Education and Information Technologies, 25, 3383-3404. https://doi.org/10.1007/s10639-020-10119-1

Gee, J. P. (2008). Video Games and Embodiment. Games and Culture, 3(3-4), 253-263. https://doi.org/10.1177/1555412008317309

Gee, J. P., \& Hayes, E. (2011). Language and Learning in the Digital Age. Abingdon, Oxon, New York: Routledge. https://doi.org/10.4324/9780203830918

Graeske, C., Lundström, S., Smith, E., Thunberg, S., \& Wallin, H. (2020). Spawn 2.0-Att spela sig till läsning. In Y. Lindberg, \& A. Svensson (Eds.), Litteraturdidaktik. Språkämnen i samverkan. Stockholm: Natur \& kultur.

Guthrie, J. T., \& Wigfield A. (1997). Reading Engagement: A Rationale for Theory and Teaching. In J. Guthrie, \& A. Wigfield (Eds.), Reading Engagement: Motivating Readers through Integrated Instruction.

Häfner, P., Dücker, J., Schlatt, C., \& Ovtcharova, J. (2018). Decision support methods for using virtual reality in education based on a cost-benefit-analyses. Paper presented at The 4th International Conference of the Virtual and Augmented Reality in Education (VARE 2018), September 17-18 2018, Budapest, Hungary.

Hardy, I., \& Rönnerman, K. (2018). Transforming professional learning: Educational action research in practice. European Educational Research Journal, 17(3), 421-441. https://doi.org/10.1177/1474904117690409

Jensen, L., \& Konradsen, F. (2018). A review of the use of virtual reality head-mounted displays in education and

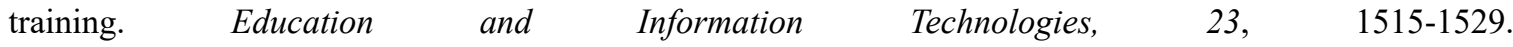
https://doi.org/10.1007/s10639-017-9676-0

Kawai, T., \& Häkkinen, J. (2019). Ergonomic guidance for virtual reality content creation. In S. Bagnara, R., Tartaglia, S. Albolino, T. Alexander, \& Y. Fujita (Eds.), Proceedings of the 20th Congress of the International Ergonomics Association (IEA 2018). IEA 2018, 417-422. https://doi.org/10.1007/978-3-319-96059-3_47

Koehler, P., \& Mishra M. J (2008). Introducing Technological Pedagogical Content Knowledge. Paper Annual Meeting of the American Educational Research Association, New York City, 24-28 May 2008.

Kwon, C. (2019). Verification of the possibility and effectiveness of experiential learning using HMD-based immersive VR technologies. Virtual Reality, 23(1), 101-118. https://doi.org/10.1007/s10055-018-0364-1

Lucas, J. (2018). Immersive VR in the construction classroom to increase student understanding of sequence, assembly, and space of wood frame construction. Journal of Information Technology in Construction, 23, 179-194. 
Makransky, G., Terkildsen, T., \& Mayer, R. E. (2019). Adding immersive virtual reality to a science lab simulation causes more presence but less learning. Learning and Instruction, 60, 225-236. https://doi.org/10.1016/j.learninstruc.2017.12.007

Mathe, M. (2020). Mapping the Landscape of Digital Game-Based Learning in Swedish Compulsory and Upper Secondary Schools Opportunities and Challenges for Teachers (Doctoral dissertation). Stockholm: Stockholms universitet.

Minocha, S., Tudor, A.-D., \& Tilling, S. (2017). Affordances of mobile virtual reality and their role in learning and teaching. In L. Hall, T. Flint, S. O'Hara, \& P. Turner (Eds.), Proceedings of the 31st international BCS, human computer interaction conference, HCI 3-7 July 2017, Swindon, UK. https://doi.org/10.14236/ewic/HCI2017.44.

Rönnerman, K. (2012). Aktionsforskning I praktiken: Förskola och skola på vetenskaplig grund. Lund: Studentlitteratur.

Shu, Y., Huang, Y.-Z., Chang, S.-H., \& Chen, M-.Y. (2019). Do virtual reality head-mounted displays make a difference? A comparison of presence and self-efficacy between head-mounted displays and desktop computer-facilitated virtual environments. Virtual Reality, 23, 437-446. https://doi.org/10.1007/s10055-018-0376-x

Shulman, L. S. (1986). Those Who Understand: Knowledge Growth in Teaching. Educational Researcher, 15(2), 4-14. https://doi.org/10.3102/0013189X015002004

SKOLFS. (2011). Förordning om läroplan för gymnasieskolan. Stockholm: Skolverket. Stockholm.

Thunberg, S. (2020). The Reading Avatar. Reading Engagement as Agency in the act of Reading in the Gamified Literature Classroom (Unpublished doctoral dissertation). Luleå: Luleå University of Technology.

Tiller, T. (1999). Aktionslärande. Forskande partnerskap i skolan. Stockholm: Liber AB.

Vetenskapsrådet. (2017). God forskningssed. Stockholm: Vetenskapsrådet.

Willermark, S. (2018). Digital didaktisk design. Att utveckla undervisningspraktiken i en och för en digitaliserad skola (Doctoral dissertation). Trollhättan: Högskolan Väst.

Zhou, Z., Jiang, S., Yang, Z., \& Zhou, L. (2019). Personalized planning and training system for brachytherapy based on virtual reality. Virtual Reality, 23(4), 347-361. https://doi.org/10.1007/s10055-018-0350-7

\section{Copyrights}

Copyright for this article is retained by the author(s), with first publication rights granted to the journal.

This is an open-access article distributed under the terms and conditions of the Creative Commons Attribution license (http://creativecommons.org/licenses/by/4.0/). 